\title{
Modelling groundwater/surface-water interaction in a managed riparian chalk valley wetland
}

\author{
A.R. House ${ }^{12 \star}$, J.R. Thompson ${ }^{2}$, J.P.R. Sorensen ${ }^{3}$, C. Roberts ${ }^{1}$, M.C. Acreman ${ }^{1}$ \\ ${ }^{1}$ Centre for Ecology and Hydrology, Crowmarsh Gifford, Wallingford, Oxfordshire, OX10 \\ 8BB, UK. Email: andhou@ceh.ac.uk \\ ${ }^{2}$ UCL Department of Geography, University College London, Gower Street, London WC1E \\ 6BT, UK \\ ${ }^{3}$ British Geological Survey, Crowmarsh Gifford, Wallingford, Oxfordshire, OX10 8BB, UK \\ ${ }^{*}$ corresponding author
}

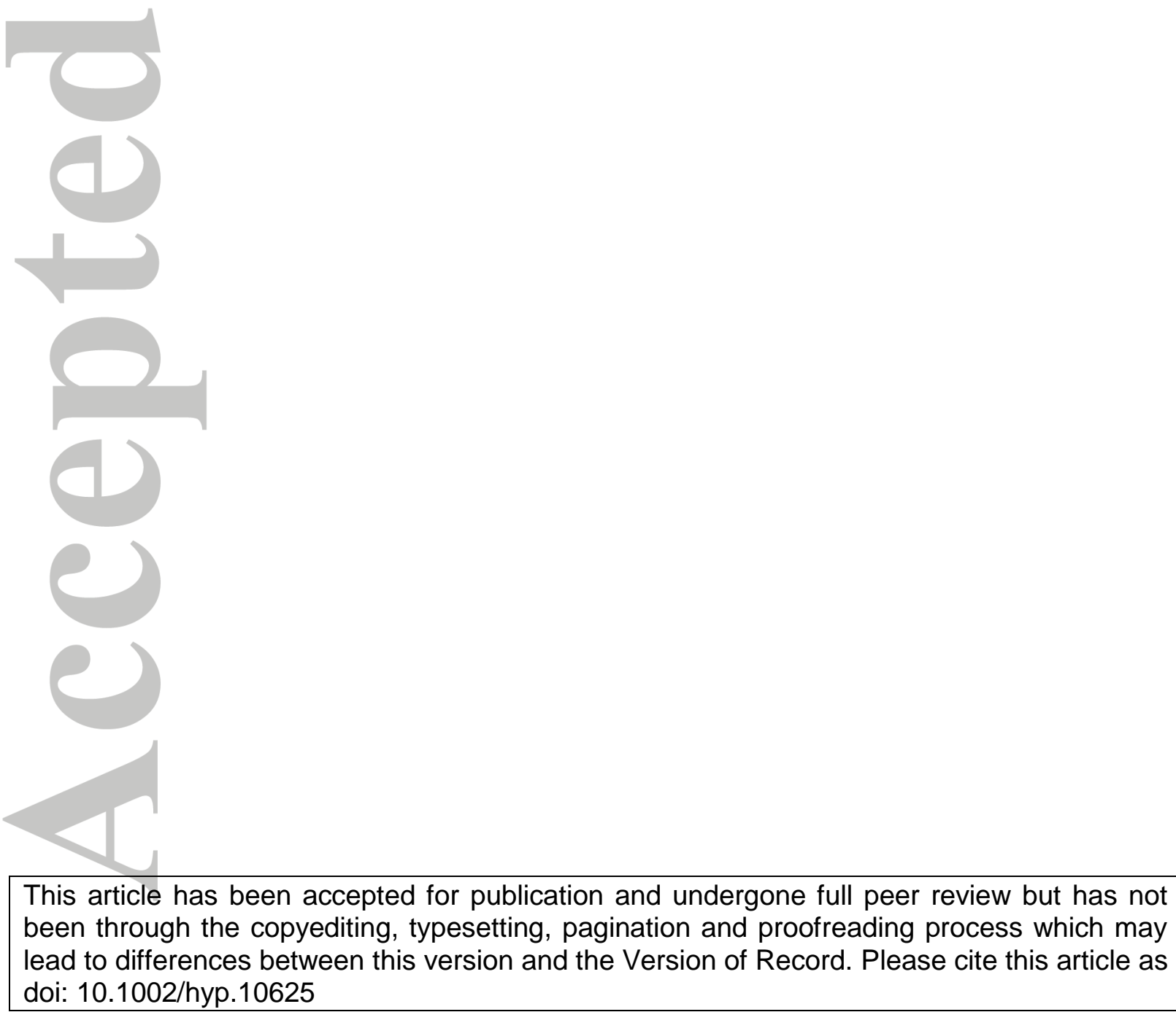




\section{Abstract}

Understanding of hydrological processes in wetlands may be complicated by management practices and complex groundwater/surface-water interactions. This is especially true for wetlands underlain by permeable geology, such as chalk. In this study, the physically based, distributed model MIKE SHE is used to simulate hydrological processes at the CEH River Lambourn Observatory, Boxford, Berkshire, UK. This comprises a 10 ha lowland, chalk valley bottom, riparian wetland designated for its conservation value and scientific interest. Channel management and a compound geology exert important, but to date not completely understood, influences upon hydrological conditions. Model calibration and validation was based upon comparisons of observed and simulated groundwater heads and channel stages over an equally split 20-month period. Model results are generally consistent with field observations and include short-term responses to events as well as longer-term seasonal trends. An intrinsic difficulty in representing compressible, anisotropic soils limited otherwise excellent performance in some areas. Hydrological processes in the wetland are dominated by the interaction between groundwater and surface water. Channel stage provides head boundaries for broad water levels across the wetland, whilst areas of groundwater upwelling control discrete head elevations. A relic surface drainage network confines flooding extents and routes seepage to the main channels. In-channel macrophyte growth and its management have an acute effect on water levels and the proportional contribution of groundwater and surface water. The implications of model results for management of conservation species and their associated habitats are discussed.

\section{Keywords}

Wetlands, hydrological/hydraulic modelling, groundwater/surface-water interaction, MIKE SHE, wetland management 


\section{Introduction}

Wetlands are widely recognised as providing valuable environmental, cultural and economic functions and services (Acreman et al., 2011). The European Habitats Directive (EEC, 1992) lists groundwater dependent wetland ecosystems as priority habitats that are particularly sensitive to environmental change. The need for sustainable wetland management is intensifying in the face of climate change as well as growing, and often competing, demands for water (Baker et al., 2009; Maltby and Acreman, 2011). The establishment and maintenance of wetlands depends primarily on the hydrological regime (Mitsch and Gosselink, 2007), as it is a key control on vegetation (Baldwin et al., 2001; Wheeler et al., 2009), fauna (Ausden et al., 2001; McMenamin et al., 2008) and biogeochemical cycling (McClain et al., 2003; Lischeid et al., 2007). Current and historical wetland management practices revolve around the maintenance of water levels required for the conservation of desired species or communities, flood mitigation, and arable or pastoral productivity (Morris et al., 2008). An ability to predict the impacts of modifications to wetlands' hydrological regimes is therefore highly desirable. Models that can accurately represent wetland hydrological processes have enormous potential in the assessment of potential degradation to the ecological character of wetlands and their management (Acreman and Jose, 2000).

In riparian wetlands, the water balance can incorporate a significant measure of groundwater (Bravo et al., 2002; Krause and Bronstert, 2005). This can be time dependent (Hunt et al., 1999), spatially heterogeneous (Hunt et al., 1996; Lowry et al., 2007; House et al., 2015), and influenced by topographical, geological and climatic factors (Winter, 1999; Sophocleous, 2002). The magnitude of the flux can exert strong controls upon the hydrological regime, nutrient status, and species composition (Wheeler et al., 2009; House et al., 2015). Thus, the impacts of abstraction, sustained low river flows, climate change, or feedback from water management activities taking place within the catchment could result in significant adverse impacts, particularly where wetlands are underlain by permeable geology, such as chalk. 
Due to the complexity of process interactions in these wetlands, quantifying a water balance through field observations alone is often impractical. Comprehensive wetland studies have instead relied on simulation of hydrological processes within fully integrated or coupled groundwater/surface-water models (Refsgaard et al., 1998; Crowe et al., 2004; Thompson et al., 2004; Krause and Bronstert, 2005; Thompson et al., 2009; Frei et al., 2010). However, these modelling studies often contain simple interpretations of the saturated zone through single layer lithology (Refsgaard et al., 1998; Thompson et al., 2004; Thompson et al., 2009; Frei et al., 2010) or transfer functions (Krause and Bronstert, 2005). Where applied to wetlands with more complex subsurface hydrogeological structures, processes have been partially represented as boundary conditions (Crowe et al., 2004).

In this study, the distributed hydrological model, MIKE SHE, is applied to a riparian wetland in the chalk lowlands of the United Kingdom (UK). Understanding and modelling of hydrological processes in the wetland is complicated by in-channel macrophyte growth and management, a compound geology, and subtle groundwater/surface-water interactions. The numerical model is used to quantify the water balance, enhance understanding of the site's hydrological functioning, identify some of the effects of current management practices, and inform future management schemes.

\section{Study Area}

\subsection{Site description}

The Centre for Ecology and Hydrology (CEH) River Lambourn Observatory $\left(51.445^{\circ} \mathrm{N}\right.$ $1.384^{\circ} \mathrm{W}$ ) contains $\mathrm{c} .10$ ha of riparian wetland adjoining a $600 \mathrm{~m}$ reach of the River Lambourn, Berkshire, UK (Figure 1). To the west of the river the wetlands are divided by the Westbrook Channel into a northern and southern meadow. The wetland and River Lambourn are designated as a Site of Special Scientific Interest (SSSI) and Special Area of Conservation (SAC) owing to their importance as habitats for Desmoulin's whorl snail 
(Vertigo moulinsiana), brook lamprey (Lampetra planeri) and bullhead (Cottus gobio). The wetland is also designated due to the presence of specific habitats (Annex 1 habitat from EU Habitat Directive: Water courses of plain to montane levels with Ranunculion fluitantis and Callitricho-Batrachion vegetation) and terrestrial plant communities (MG8 vegetation community of the UK National Vegetation Classification (Rodwell, 1991)).

The site is located $13 \mathrm{~km}$ downstream from the ephemeral source of the River Lambourn at Lynch Wood, Lambourn $\left(51.512^{\circ} \mathrm{N}, 1.529^{\circ} \mathrm{W}\right)$. The river drains the Chalk of the Berkshire Downs and is characterised by a large baseflow component. At Shaw, the nearest gauging station $5 \mathrm{~km}$ downstream of the observatory, the river has a base flow index of 0.96 and a mean discharge of $1.73 \mathrm{~m}^{3} \mathrm{~s}^{-1}$ (Marsh and Hannaford, 2008).

The wetland was managed as flood pastures and water meadows until the middle to late $20^{\text {th }}$ century (Everard, 2005). Maps dating to the 1880s show a corresponding network of predominantly linear conduits, sluices and aqueducts. Most of these channels have naturally infilled and are absent from current maps, although the relic drainage network is still evident in the topography. A single sluice gate remains, positioned approximately halfway along the Westbrook and operated by the local community. Grazing gradually came to an end on the water meadows from the mid-1960s to the 1980s. This is reflected in the current prevalence of tall-herb fen vegetation communities through the site (House et al., 2015). There is some succession, with plant communities graded from swamp and fen dominated by reed sweetgrass (Glyceria maxima) and lesser pond sedge (Carex acutiformis) in the north, to remnants of the MG8 community in the south. Current management is confined to the river, where instream macrophyte growth is cut back periodically to maintain flood conveyance and lower water levels (Old et al., 2014).

The site is underlain by the Seaford Chalk Formation, dipping at $1-2^{\circ}$ to the southeast (Allen et al., 2010), and comprising a uniform soft to medium-hard chalk with frequent flint nodules. The surface of the chalk has been highly weathered, in places, producing a low permeability 
'putty chalk' (Younger, 1989) up to $5 \mathrm{~m}$ thick. River terrace deposits and alluvium up to $7 \mathrm{~m}$ thick overlie the Chalk, consisting primarily of coarse gravels with some sand (Chambers et al., 2014). These are thicker and more continuous in the north meadow, nearer to the course of the river. In the south the gravels are more variable and thin to the west, almost disappearing towards the southwest boundary of the site. In their lower layers there is often

a high proportion of reworked chalk material. Above the gravels a layer $0.4-2 \mathrm{~m}$ thick consists predominantly of peat (Chambers et al., 2014).

\subsection{Conceptual model}

A field campaign using 3D electrical resistivity tomography (ERT) (Chambers et al., 2014), along with temperature, hydrochemistry and vegetation surveys (House et al., 2015), has enabled the development of a conceptual model (Figure 2). The peat and gravels are considered to have good hydraulic connectivity, with head boundaries at the River Lambourn and Westbrook broadly controlling water levels across the wetland. A double aquifer system of gravels and Chalk is mostly separated by a confining layer of low permeability 'putty' chalk. Leakage occurs between the gravels and Chalk where the putty chalk is thin or absent, causing localised variations in water levels. These are concomitant with relic infilled channels in the peat and occur mainly in the north meadow.

\subsection{Site instrumentation}

Piezometers were selected from a wider existing array installed in January 2012, based upon data availability, and numbered 1-7 (Figure 1). These were supplemented by piezometers installed in May 2013 to target discrete areas of groundwater upwelling (locations 8-12; Figure 1). Water levels were monitored in pairs of piezometers installed in both the peat $(P)$ and gravel $(G)$. Exceptions include locations 11 and 12 with gravel piezometers only, and 7 and 10 with peat piezometers only. Gravel piezometers were screened approximately $2.5-3.5 \mathrm{~m}$ bgl (below ground level) whilst peat piezometers were 
screened across the entire peat thickness. A chalk (C) piezometer is also located at site 3 , screened at 9.5-10.0 m bgl.

Peat and gravel groundwater heads were monitored every five minutes using either In-Situ Level Troll@ 500s or SWS Divers ${ }^{\circledR}$ installed to a consistent depth of $3 \mathrm{~m} \mathrm{bgl}$ in gravel piezometers and to the base of the peat in peat piezometers. Groundwater heads are routinely checked by manually dipping observed water levels to quality control logged data susceptible to drift (Sorensen and Butcher, 2011). Channel stage was observed monthly at seven stage boards along the River Lambourn (L1, L3-L7) and three in the Westbrook (W1W3). River Lambourn stage was also recorded every five minutes at L2 using a SWS Diver®.

Continuous 15 minute averaged meteorological observations were logged using an automatic weather station (AWS). Air temperature and relative humidity are recorded using a CS215 ${ }^{\mathrm{TM}}$ sensor. An R M Young $03101^{\mathrm{TM}}$ cup anemometer measures wind speed. Solar radiation was recorded with a $\mathrm{LP}^{\mathrm{T}} \mathrm{2}^{\mathrm{TM}}$ pyranometer. Accumulated 15 minute precipitation was measured with a ARG100 $100^{\mathrm{TM}}$ tipping bucket rain gauge.

\section{MIKE SHE Model}

\subsection{Model development}

MIKE SHE is an integrated modelling system which simulates the land-based phase of the hydrological cycle (Graham and Butts, 2005). Developed originally from the Système Hydrologique Européen (SHE) (Abbott et al., 1986a; Abbott et al., 1986b) by the Danish Hydraulic Institute (DHI), it has been utilised for international river basins (Andersen et al., 2001; Stisen et al., 2008; Thompson et al., 2013; Thompson et al., 2014), catchments with areas of hundreds to thousands of $\mathrm{km}^{2}$ (Feyen et al., 2000; Huang et al., 2010; Singh et al., 2010; Singh et al., 2011), to small $\left(<50 \mathrm{~km}^{2}\right)$ catchments and individual wetlands (Refsgaard et al., 1998; Al-Khudhairy et al., 1999; Thompson et al., 2004; Thompson, 2012). Although 
often labelled as a deterministic, fully distributed and physically based model, the complexity of process representation may be varied to include empirical and semi-distributed methods. The model may thus be built iteratively in line with data availability and process understanding. This flexibility, along with a proven applicability for simulating wetland hydrological systems (Refsgaard et al., 1998; Al-Khudhairy et al., 1999; Thompson et al., 2004; Staes et al., 2009; Thompson et al., 2009), underpins its use in the current study.

Model time step is adjusted automatically within MIKE SHE dependent on precipitation and infiltration rates (DHI, 2009). The model domain was provided by the River Lambourn Observatory formal boundary with a total area of 10 ha. This coincides with the perimeters of the wetland areas at the extents of the valley bottom. A grid size of $1 \times 1 \mathrm{~m}$ was selected from a series of model runs which showed little change in simulated groundwater heads for grid sizes between $0.5 \times 0.5 \mathrm{~m}$ and $10 \times 10 \mathrm{~m}$ (after Vázquez et al., 2002). The chosen resolution, which produces 101,689 grid cells within the model domain, provides a good balance between the representation of physical characteristics of the site, such as topography, and computation time.

Detailed topographic data were provided by a ground survey combined with LiDAR. For the survey, differential GPS (dGPS) was used to georeference 2815 locations with an approximate grid resolution of $3 \times 3 \mathrm{~m}$. Dense scrub and watercourse boundaries confined the survey extent. To supplement dGPS coverage, $1 \times 1 \mathrm{~m}$ resolution LiDAR data were resampled to the $1 \times 1 \mathrm{~m}$ MIKE SHE grid (Figure 3).

A single long grass vegetation type was used to represent land cover across the model in line with the dominance of tall-herb fen at the site (House et al., 2015). Temporal variations in leaf area index and root zone depth, required for the interception and evapotranspiration modules, were taken from the literature (Breuer et al., 2003) and an existing DHI (2009) vegetation properties file. The overland flow component was also uniformly distributed, with the Manning's $\mathrm{n}$ roughness coefficient employed as a calibration term. 
The 1D form of the Richards equation used within the unsaturated zone module employed a spatially uniform soil profile comprising peat to a depth of $1 \mathrm{~m}$. Values for the Van Genuchten (1980) expression of the soil moisture retention curve were obtained from the literature (Letts et al., 2000). Infiltration rate and effective saturation were parameterised through calibration.

The saturated zone was characterised as a four layer geological model with peat overlying gravels over a discontinuous layer of putty chalk, and Chalk bedrock beneath. The 3D finite difference Darcy flow method was employed to calculate subsurface flow. Depths to the gravel-peat interface were taken from a manual probing survey of 2815 locations in conjunction with the topographic survey (Chambers et al., 2014). The gravel-chalk interface was derived from a 3.1 ha 3D ERT survey of the meadows using a resistivity isosurface extended by trilinear interpolation from intrusive boreholes where the interface could be identified in core retrievals (Chambers et al., 2014). This was extended to the edges of the model domain by bilinear interpolation within MIKE SHE. The horizontal extent of the putty chalk was also extracted from the resistivity model using a representative range of resistivities (10 - $75 \Omega \mathrm{m}$ ) following Crook et al. (2008). Within the saturated zone setup this was specified as a $1 \mathrm{~m}$ layer with relatively low hydraulic conductivity $\left(1 \times 10^{-10} \mathrm{~ms}^{-1}\right)$ at the top of the Chalk bedrock. Gaps in the putty chalk were allocated the same hydraulic conductivity as the Chalk, taken from the literature as $4.4 \times 10^{-4} \mathrm{~ms}^{-1}$ (Younger, 1989). Vertical and horizontal hydraulic conductivities of the peat and gravels were varied during model calibration.

For the Chalk aquifer, head boundaries were based on observations from a piezometer at 3C (Figure 1). Observed values were adjusted to differences in elevations at $50 \mathrm{~m}$ intervals along all sides of the model domain by linear interpolation. Gravel boundaries were set to a constant flux gradient 0.003 in the north and south, based upon observations from the piezometer network and following the topographic gradient. The remaining boundaries, 
where the gravel thins to the valley edge, were defined as zero flow. Zero flow boundaries were assigned around the peat and putty chalk layers where lateral flow was expected to be minimal due to low hydraulic conductivities.

The river network was digitised in MIKE 11 from Ordnance Survey MasterMap 1:1250 raster data. The fully dynamic 1D St Venant equations were used to describe channel flow with all MIKE 11 branches specified as being coupled to MIKE SHE. Channel cross-section profiles applied to the network were based on dGPS surveys conducted at 44 locations along the Westbrook and 42 along the River Lambourn. Bank elevations were taken from the MIKE SHE topographic grid with points across the cross-section specified as depths relative to the banks (Thompson et al., 2004). The channel bed was specified to be in full contact with the saturated zone, so that exchange between the river and aquifer was controlled by the hydraulic conductivity of the aquifer rather than river bed material. This was deemed appropriate due to the nature of the channel substrate and high base flow index.

Inflows for the upstream channel boundary, which were specified as a mean 15 minute discharge, were derived from a relationship between monthly measurements of discharge at L1 (Figure 1) using an electromagnetic flow meter and the corresponding flow at the downstream Shaw gauging station. The downstream boundary was set to follow monthly stage observations at L7 (Figure 1) specified on a 15 minute basis by linear interpolation.

To account for instream macrophyte (weed) growth and its cutting within the Lambourn, channel bed roughness (Manning's n) was manipulated as a proxy since MIKE 11 does not contain a method to represent such temporal changes in instream vegetation explicitly. Weed cuts on $1 / 5 / 2013,16 / 7 / 2013,21 / 5 / 2014$ and $23 / 7 / 2014$ signified rapid decreases in channel bed roughness, which otherwise fluctuated in response to the growing season. A 15 minute series of Manning's $n$ values was derived from measurements of cross-section geometry and stage at L1 (Figure 1), energy slope between stage boards at L1 and L2, and 
the derived 15 minute discharge at L1. This was applied as a multiplication factor to a fixed channel roughness at each time step.

Meteorological data were supplied by the automatic weather station installed in the south meadow. This provided 15 minute precipitation and potential evapotranspiration calculated using the Penman-Monteith formula (Monteith, 1965). MIKE SHE calculates actual evapotranspiration from these specified potential rates and computed soil moisture in the root zone using the Kristensen and Jensen (1975) method.

\subsection{Calibration and validation}

A split sample approach was used to calibrate and validate the model. Based on data availability, the periods $1 / 2 / 2013-1 / 12 / 2013$ and $1 / 12 / 2013-1 / 10 / 2014$ were used for calibration and validation, respectively. Calibration and validation was based on comparison between observed and simulated groundwater heads for the network of piezometers in the wetland as well as channel stage from the stage boards installed within the Lambourn and Westbrook.

In accordance with the literature (Refsgaard and Storm, 1995), the number of calibration parameters was minimized. Parameters adjusted during calibration included effective saturation and infiltration rate in the unsaturated zone, the vertical and horizontal hydraulic conductivity of the peat and gravel in the saturated zone, and Manning's $\mathrm{n}$ roughness coefficient for overland flow.

An automatic multiple objective calibration was performed based on the shuffled complex evolution method (Duan et al., 1992; Madsen, 2000; Madsen, 2003). Equally weighted model performance statistics, the root mean square error (RMSE) and absolute value of the average error, were aggregated into a single objective function with a transformation that compensates for differences in magnitudes (Madsen, 2003). This provided the autocalibration routine with a measure of convergence, evaluated at the model time step. 
Manual adjustment of calibration parameters to further improved model performance was assessed using the Pearson correlation coefficient $(R)$, the Nash-Sutcliffe coefficient (R2) (Nash and Sutcliffe, 1970) and the root mean square error (RMSE) of the deviation between observed and simulated groundwater and channel water levels. A scheme adapted from Henriksen et al. (2008) was used to classify model performance based on the values of these statistics.

\section{Results}

\subsection{Model calibration and validation}

Final values for the seven calibration parameters indicate values of horizontal and vertical hydraulic conductivity of the peat are consistent with the scale-dependency of peat hydraulic conductivity reported by Bromley et al. (2004) (Table 1). Higher values are obtained with increasing volumes due to preferential flow routes provided by features such as root holes and abandoned infilled ditches. Gravel hydraulic conductivity values are supported by similar measurements from superficial deposits throughout the Thames basin (Bricker and Bloomfield, 2014). Model performance statistics for the calibration period for all 20 piezometers and the ten stage boards Show that ,according to the classification scheme, model performance is generally "very good" to "excellent". Mean values for RMSE, R and R2 are 0.063 m ("very good"), 0.92 ("excellent") and 0.75 ("very good") respectively (Table 2). Model results are notably better for the gravel groundwater heads compared to those in the peat. Out of 30 values for the gravel (ten piezometers $\times$ three statistics), 23 are classified as "excellent" with the remainder classed as "very good". In contrast 15 of the 30 values for the peat piezometers are classed as "excellent" and ten as "very good". Four of the remaining five values are classed as "fair" whilst the R2 value for 2P (0.35) is "poor" (although the RMSE and R values are "very good" and "excellent", respectively). Model performance for channel stage is predominantly "very good" (16 out of 30 values) followed by "excellent" (10 values) although three R2 values and one RMSE value are classified as only "fair". 
Performance for the validation period is in general very similar to the calibration period (Table 2). The mean values for RMSE, $R$ and $R 2$ are $0.063 \mathrm{~m}$ ("very good"), 0.94 ("excellent") and 0.77 ("very good"), respectively (Table 2). For the gravel piezometers 16 of the statistics are classified as "excellent" with the remainder being "very good". Slightly more of the statistics have a higher value for the calibration period than the validation (16:10 with four unchanged). For the peat piezometers, an equal number (13) of the statistics are classed as "excellent" or "very good" with two each being classified as "fair" or "poor". Performance as indicated by these statistics is improved for the validation period for 12 and reduced for 17 but in general changes are small in magnitude (one value remaining the same). The previous classification of R2 as "poor" for P2 is replaced by a "very good" whilst the same statistics for $5 \mathrm{P}$ and $8 \mathrm{P}$, which for the calibration period were classed as "very good", are now "poor". A marked improvement in the model's ability to simulate channel stage for the validation period is evident with 19 of the 30 statistics having higher values for latter period (ten lower, one unchanged). Performance is predominantly classified as "excellent" (22 statistics). With the exception of RMSE for W2 ("fair"), the others are classified as "very good".

The generally "excellent" or "very good" performance of the model in terms of reproducing the observed gravel groundwater head elevations are shown throughout both the calibration and validation periods (Figure 4). The simulated heads clearly display the seasonal rise and fall observed throughout the site as well as the impacts of individual rain events. In addition, the effects of the weed cuts in the form of the subsequent rapid declines in groundwater head are clearly simulated by the model suggesting good representation of the exchange between the river and the underling gravels. Some over prediction towards the end of the validation period is noticeable at $1 \mathrm{G}, 2 \mathrm{G}$ and $5 \mathrm{G}$ (Figure 4). Groundwater heads at some locations with upwelling ( $8 \mathrm{G}, 9 \mathrm{G}$ and $12 \mathrm{G}$ ) are under predicted during the period of high head elevation at the beginning of 2014 although at $11 \mathrm{G}$ this over estimate of head elevation 
is not apparent. Weaker performance is apparent at $3 \mathrm{G}$ and $6 \mathrm{G}$, with under prediction notable during periods of high head.

As noted previously, model performance for the peat groundwater head elevations is inferior to the gravels (Figure 5). The impacts of many of the individual rain events are simulated as are the rapid declines in level associated with the weed cuts in the River Lambourn. Model performance tends to be better at low head elevations. Nonetheless, observed peat groundwater head at locations P1-P7 show sharp head increases throughout these periods of low elevations that, although evident, are of smaller magnitude in the model results. Relatively weak performance is noticeable at $4 \mathrm{P}$ and $5 \mathrm{P}$ throughout both the calibration and validation periods, and at $8 \mathrm{P}$ in the latter. In contrast, despite the issues discussed above, relatively good performance is achieved at the other locations, especially $1 \mathrm{P}, 2 \mathrm{P}, 9 \mathrm{P}$ and $10 \mathrm{P}$ although there is a general over prediction during periods of high head.

Observed and simulated channel stages correspond well on the whole although, with the exception of L2, observations are not as frequent as those for gravel and peat groundwater heads (Figure 6). At L2, generally good agreement between observed and simulated river levels in the Lambourn is obtained. Elsewhere, there is a general under prediction of stage during the validation period although, as previously reported, the model performance statistics are generally classified as "very good" to "excellent". The weakest performance is for W2, especially through the validation period, with the simulated water levels often falling well outside observed stage The model clearly simulates the rapid drops in stage due to the four weed cuts that drive the resulting declines reported at these times in the peat and gravel whilst the increases over the beginning of 2014 are also represented.

\subsection{Water balance}

The modelled monthly water balance is summarised 3so that surface water (SW) represents net outflow (channel and overland outflow minus inflow), while groundwater (GW) represents net inflow (groundwater inflow minus outflow), and baseflow (B) the exchange between 
channel and gravels with negative values signifying loss to gravels (Table 3 ). The degree to which surface water and groundwater dominate the water balance is apparent, with SW and GW comprising 44.2 and $43.4 \%$ of total flow $(5849.4 \mathrm{~mm})$ respectively. Precipitation $(\mathrm{P})$ and evapotranspiration (ET) are of secondary importance in transferring water into and out of the site, and constitute 6.3 and $5.7 \%$ of total flow respectively. Groundwater, surface water, precipitation and evapotranspiration are, perhaps unsurprisingly, interlinked, with associated increases and decreases in the first two terms reflecting changes in the balance between the second two. For example, the winter flood period from December 2013 to February 2014 is marked by the increase in water within GW and SW, with both peaking in January 2014, the month with the largest precipitation input. Although storage components are small annually (SWS and GWS), there is obvious temporal variability, with monthly storage changes often as significant as $\mathrm{P}$ and $\mathrm{ET}$. Increases in evapotranspiration over the spring and summer periods, when precipitation is relatively low, correspond to periods of reduced water storage.

Selected principal components of the water balance over the full simulation period, with groundwater split by vertical direction and geological layer, are shown in Figure 7 . The correspondence between increases in surface water flux and rainfall events is clear. In addition the influence of the weed cuts on surface fluxes is clearly demonstrated. The highest peaks occur at the time of the weed cuts in 2013 when rainfall inputs are low or absent, and signify the flush of surface water within the floodplain to channels and in turn to the river in response to the fall in channel stage.

Upward flows of groundwater between layers are consistently higher than downward flows (Figure 7). The latter are generally in line with surface water flux, although peak responses are muted in the gravels. However, in the month before each of the weed cuts in 2013, downward flows increase gradually. These increases are mirrored by marked decreases in upward flows, especially between the chalk and gravels. Upward exchanges from the gravels increase sharply with rainfall events and the weed cuts yet follow the general pattern 
of upward chalk groundwater fluxes. Flow upwards from the chalk displays an inverse pattern, with rapid increases during and immediately after weed cuts, yet decreases in association with rainfall events. Post weed cut flows from the gravels to the peat are maintained at a higher level, corresponding to increased upward flow from the chalk. However, the $23 / 7 / 2014$ weed cut has comparatively minimal impact. Aside from the conspicuous human induced effects due to the weed cuts, strong seasonality is noticeable, with volumes of groundwater exchanges grading between winter wet periods and summer dry spells.

\subsection{Surface water flooding and groundwater upwelling}

The extent and depth of simulated surface water flooding at periods of high flow corresponds closely with topography (Figure 3). Shallow relict channels from the historical water meadow system are apparent as areas of relatively deep flooding. Elsewhere much of the flooding appears linked to the main channel system. This is especially the case for areas adjacent to the Westbrook as it flows through the centre of the site, and towards the River Lambourn in the southeast. However, in the north meadow and southeast section of the south meadow, areas of flooding not directly linked to the main channel system still occur.

Simulated gravel and peat head gradients show an overall resemblance evident in both wet and dry periods (Figure 8). Groundwater mounding can be seen to occur in both the northern meadow and in the northern part of the south meadow around the Westbrook. A discrete area of particularly high groundwater head is simulated towards the north of the site. These elevated heads in the north meadow are concomitant with locations where putty chalk is absent at the interface between the chalk and gravel aquifers (Figure 1). There are additional areas of higher head and hence steeper local head gradients to the centre east, and are especially noticeable in the gravels (Figure $8 a$ and $8 b)$. Small scale head variations in the gravels in line with the Lambourn are evident during the high peak (Figure 8b). Gradients in the peat appear influenced by the topography of the relic drainage network 
during this peak (Figure 8d), yet less so at low levels (Figure 8c). In general, head elevations follow the topographic gradient in line with the valley at peak elevations (Figure 8b and 8d). However, there is a shift in the direction of groundwater flow from towards the south to the southwest as head elevations drop (Figure 8a and 8c).

\section{Discussion}

\subsection{Model performance}

Although the model generally simulates conditions very well across the River Lambourn Observatory, there are clearly spatial and temporal disparities in model performance. The superior representation of water levels in particular areas and within the different geological layers highlights the influence of heterogeneity in structure and process at the site scale. Such results also underline the importance of robust field survey and monitoring approaches at spatial resolutions which are sufficient to incorporate this heterogeneity.

Model performance is inferior within the peats. This is especially true when water levels are high and could be due to the inability of MIKE SHE to represent compressible, anisotropic soils, instead defining the hydraulic properties of each geological unit as being temporally and spatially constant. Indeed, incorporation of the effects of soil deformation into hydrological models has, with a few exceptions (Camporese et al., 2006), been generally overlooked. However, peat hydraulic conductivities may vary over relatively short distances by several orders of magnitude (Kneale, 1987; Bragg, 1991; Bromley et al., 2004), seasonally by up to an order of magnitude (Price, 2003; Kettridge et al., 2013), and with depth by several orders of magnitude (Clymo, 2004; Baird et al., 2008). The effectiveness of applying rigid soil theory to peat soils has therefore been questioned (Brown and Ingram, 1988; Baird and Gaffney, 1994). Price (2003) found that saturated hydraulic conductivity was highly correlated to water table depth, with increases of up to 2 orders of magnitude observed after a $0.5 \mathrm{~m}$ rise in water table elevation. Peat liquefaction with saturation and the 
associated increase in hydraulic conductivity could explain the overestimation of head in the MIKE SHE model when water elevations are high, particularly in areas of groundwater upwelling (8P-10P).

Occurrences of silt, sand and gravel within the peat (Allen et al., 2010) could also contribute to local variations in hydraulic conductivity. The presence of these small-scale variations in substrate characteristics are difficult to establish in the field, yet at the applied model grid resolution could have a significant impact on simulated groundwater flow and levels. Variations in the alluvial composition may account for the poorer performance in certain areas, for example at 5P. Additionally, the peat piezometers of the pre-existing array (1P-7P) were installed with the slotted screen extending above ground level. The sharp observed responses in head during periods of low water levels may be a reflection of direct influx of water from the surface during rain events. The exaggerated plateau of high head elevation at 4P may thus be due to surface water above the open level of the piezometer. In contrast, at locations $8 \mathrm{P}-10 \mathrm{P}$, where bentonite was used to seal new piezometers with closed screens above ground level, event peak head elevations match well. These instrumental issues could therefore produce misleading results, where otherwise the model could be performing effectively. The influx of surface water into piezometers, though, has not been directly observed and may otherwise be a result of substrate variations and peat compressibility. Differences in magnitude between observed and simulated event peaks vary noticeably by location, while the timings match well. Hence, measurements from these piezometers were not excluded from this study. Gravel head elevations are generally simulated very well by the model. Where deviations occur they fall into two groups; locations where the model underestimates levels (3G, 6G-9G and 12G) and those locations where levels are overestimated towards the end of the simulation period ( $1 \mathrm{G}, 2 \mathrm{G}$ and $5 \mathrm{G}$ ). The Electrical Resistivity Tomography (ERT) survey revealed significant braided structures in the gravels (Chambers et al., 2014). These suggest large differences in gravel porosity across the site which would cause localised and depth dependent variations in hydraulic conductivity, as 
could quantities of reworked chalk in lower levels (Allen et al., 2010). Although the features could help explain the underestimation at high heads, the over predicted gravel head elevations are more problematical and may be due to inadequacies in the boundary conditions.

Discrepancies between simulated and observed channel stage may in part be due to discrete changes in channel bed roughness. The growth and distribution of instream vegetation is affected by many factors, amongst which channel morphology, bed material and adjacent conditions will contribute. Localised effects of macrophyte growth on bed roughness are not accounted for within the model; instead, a uniform resistance factor is applied throughout the MIKE 11 river model. An unmonitored sluice gate located just upstream of W2 could additionally account for the poor representation of channel stage at this location. Local residents adjust the control structure in order to maintain the aesthetics of a pool feature and the times when the sluice is open or closed are unfortunately not recorded.

\subsection{Groundwater/surface-water interaction}

Surface water and groundwater are inextricably linked and crucial to processes in the wetland. The channels, gravels and peat are hydraulically connected. Model results show that gravel waters provide a significant contribution to the site, supporting earlier findings of research in the Lambourn (Grapes et al., 2006; Abesser et al., 2008). Channel stage acts as a head boundary and controls broad water levels within both the gravels and peats. It also influences responses in groundwater flow from the Chalk aquifer. Chalk groundwater is an important source of water into the Lambourn Observatory, discharging into the gravel aquifer and wetland through gaps in the putty chalk and resulting in locally elevated heads. Rapid reductions in head from weed cutting in the River Lambourn draw water up from the chalk, increasing the rate of upward groundwater flow. Conversely, increased stage resulting from storm events raises head elevations within the gravels and peats, inhibiting upwelling from 
the chalk groundwater. The influx of surface water into the gravels at high stage drives the increases in gravel head.

The longer-term trend of surface water outflow follows the seasonal pattern of groundwater inflow. When heads in the Chalk are high, so are levels in all components of the system. This reflects larger-scale catchment processes and the position of the site in a chalk valley bottom with a groundwater fed river. Surface flooding is a combination of seepage from upwelling groundwater, and overbank flow routed from the channels by the relic drainage network. The simulated areas of groundwater mounding in the north meadow and associated flooding support earlier findings in the field (House et al., 2015). To the east, steeper head gradients correspond with the mouth of a dry valley. However, the cause of the high heads around the Westbrook is less clear. The area does, however, fall beyond the extents of the detailed topographical and geological surveys, with access limited by dense vegetation. It is difficult to assess whether the results are from a real or interpolated feature, and highlight the importance of high-resolution field data.

\subsection{Management implications}

Results of the field monitoring programme, which are replicated by the model results, demonstrate that instream weed cutting has profound effects upon the wetland's hydrological processes. Wetland plant species and communities have preferences to certain water levels and depths to groundwater (Elkington et al., 1991; Newbold and Mountford, 1997; Gowing et al., 2002; Wheeler and Brooks, 2004; Wheeler et al., 2009). The speciespoor swamps prevalent at the Lambourn Observatory reflect the duration and magnitude of drops in groundwater levels from weed cutting (Old et al., 2014). However, the unaccounted effects of groundwater upwelling in locally raising heads and maintaining areas of standing water may be vital to the promotion of certain species.

The degree to which water sources interact will affect plant species distribution through the available nutrient budget. Previous hydrochemical analysis has shown that chalk 
groundwater upwelling into the peat contains high concentrations of $\mathrm{NO}_{3}$ and $\mathrm{SO}_{4}$ and low $\mathrm{P}$ concentrations (House et al., 2015). Elsewhere, the peat contains reducing waters low in $\mathrm{NO}_{3}$ and $\mathrm{SO}_{4}$, yet high in $\mathrm{P}$. These different chemical environments were found to promote distinct plant species. High concentrations of nitrate supported localised growth of greater tussock sedge (Carex paniculata) within surrounding fen communities in higher phosphate waters. Artificial lowering of water levels will promote aerobic conditions within the peat, whilst increases in groundwater contributions will cause further changes in the chemical environment. Such changes could have localised ecological effects that are not accounted for by generalised site management practices. Aerobic conditions can also lead to peat oxidisation and release of $\mathrm{CO}_{2}$, whereas wet peat may generate methane; hence, soil water levels are therefore important for managing greenhouse gas emissions from wetlands (Acreman et al., 2011).

The meadows of the Lambourn Observatory once supported breeding snipe (Gallinago gallinago) (Everard, 2005), but these are no longer present and a general decline in the UK and Europe has been linked to losses in lowland wet grassland (Ausden et al., 2001). The species breeds in wet areas where the softer ground allows them to easily forage for food (Smart et al., 2008). Waterlogged features support a higher biomass of surface-active and aerial invertebrates (Plum, 2005; Eglington et al., 2010), and the wading birds which feed on them (Milsom et al., 2000; Ausden et al., 2001; Milsom et al., 2002). Consistently high groundwater levels therefore benefit snipe and other wading birds and are also considered essential for Desmoulin's whorl snail, the species which contributes to the site's scientific and nature conservation status (Tattersfield and Mclnnes, 2003). Site hydrology is a principal factor in determining the distribution of the snail, with optimum conditions found where water levels remain above ground level year round. A survey undertaken in 2012 showed a reduced presence of the snail suggesting a gradual decline since the $1990 \mathrm{~s}$ (Natural England, 2012). The roles of groundwater upwelling, channel stage, and the relic 
surface drainage network in the distribution of water levels are thus important considerations for conservation management.

\section{Conclusions}

The potential of MIKE SHE to model wetlands with a complex subsurface architecture has been demonstrated for the River Lambourn Observatory, a lowland riparian wetland in a chalk valley bottom of southeast UK. Findings support a conceptual model, with hydrological processes in the wetland dominated by the interaction between groundwater and surface water. Channel stage provides head boundaries for broad water levels across the wetland, whilst areas of upwelling from the Chalk aquifer control discrete head elevations. A relic surface drainage network confines flooding extents and routes seepage to the main channels.

Model performance is generally very good. Results are consistent with field observations and follow short-term responses to hydrological and management events, as well as the longer-term seasonal trend. The impact of instream weed cutting is well represented, and affects water levels throughout the site. The interaction between surface water and groundwater is also markedly affected by weed cutting. This influences head variations across the wetland, the proportional contribution of each water source, and the maintenance of areas of standing water. The water balance will dictate species composition and distribution through the controlling influences of water levels and the nutrient budget. The findings demonstrate the necessity to consider not only surface water, but also groundwater in site management schemes. Indeed, separation of the terms is counterproductive in such applications. This is especially important when balancing the promotion of desired species and their associated habitats for conservation with productivity and flood risk mitigation.

The MIKE SHE model of the Lambourn Observatory may be used to investigate the hydrological effects of environmental changes, whether from alterations to climate, 
groundwater abstraction, channel morphology or vegetation management. Representative boundary conditions could be obtained through links to existing regional groundwater models (e.g. Jackson et al., 2011), though differences in model grid resolution would need to be addressed.

Further application of ecological indices to model results will allow assessment of the ecological sensitivity of the wetland to environmental changes (e.g. Thompson et al., 2009). Specific water level requirements of plants and animals in the wetland, and environmental flows in the channels, could be linked to species maintenance or succession. The addition of a nutrient or contaminant transport module would further aid impact assessment for particular species and communities. The MIKE SHE model of the Lambourn Observatory therefore represents an essential tool for understanding the wetland ecosystem and its response to change and for developing management approaches.

\section{Acknowledgements}

Seb Uhlemann and Andy Newell (BGS) provided ERT data. The Environment Agency Geomatics Group provided LiDAR data. Ordnance Survey MasterMap data are CCrown Copyright and an Ordnance Survey/EDINA supplied service. Funding for the study was provided by the Natural Environment Research Council (NERC). 


\section{References}

Abbott, M., Bathurst, J., Cunge, J., O'connell, P., Rasmussen, J., 1986a. An introduction to the European Hydrological System-Systeme Hydrologique Europeen,"SHE”, 2: Structure of a physically-based, distributed modelling system. Journal of hydrology, 87(1): 61-77.

Abbott, M.B., Bathurst, J.C., Cunge, J.A., O'Connell, P.E., Rasmussen, J., 1986b. An introduction to the European Hydrological System-Systeme Hydrologique Europeen,"SHE”, 1: History and philosophy of a physically-based, distributed modelling system. Journal of hydrology, 87(1): 45-59.

Abesser, C., Shand, P., Gooddy, D., Peach, D., 2008. The role of alluvial valley deposits in groundwater-surface water exchange in a Chalk river. IAHS Press.

Acreman, M. et al., 2011. Trade-off in ecosystem services of the Somerset Levels and Moors wetlands. Hydrological Sciences Journal, 56(8): 1543-1565.

Acreman, M. et al., 2007. Practical approaches to hydrological assessment of wetlands lessons from the UK. Wetlands: Monitoring, modelling, and management. Taylor \& Francis, London: 287-292.

Acreman, M.C., Jose, P., 2000. Wetlands. In: Acreman, M.C. (Ed.), Hydrology of the UK: a study of change. Routledge, London.

Al-Khudhairy, D.H.A., Thompson, J.R., Gavin, H., Hamm, N.A.S., 1999. Hydrological modelling of a drained grazing marsh under agricultural land use and the simulation of restoration management scenarios. Hydrological Sciences Journal, 44(6): 943-971. 
Allen, D.J. et al., 2010. Interaction between groundwater, the hyporheic zone and a Chalk stream: a case study from the River Lambourn, UK. Hydrogeology journal, 18(5): 1125-1141.

Andersen, J., Refsgaard, J.C., Jensen, K.H., 2001. Distributed hydrological modelling of the Senegal River Basin-model construction and validation. Journal of Hydrology, 247(3): 200-214.

Ausden, M., Sutherland, W.J., James, R., 2001. The effects of flooding lowland wet grassland on soil macroinvertebrate prey of breeding wading birds. Journal of Applied Ecology, 38(2): 320-338.

Baird, A.J., Eades, P.A., Surridge, B.W., 2008. The hydraulic structure of a raised bog and its implications for ecohydrological modelling of bog development. Ecohydrology, 1(4): 289-298.

Baird, A.J., Gaffney, S.W., 1994. Cylindrical piezometer responses in a humified fen peat. Nordic Hydrology, 25(3): 167-182

Baldwin, A., Egnotovich, M., Clarke, E., 2001. Hydrologic change and vegetation of tidal freshwater marshes: Field, greenhouse, and seed-bank experiments. Wetlands, 21(4): 519-531.

Baker, C., Thompson, J.R., Simpson, M., 2009. Hydrological dynamics I: Surface waters, flood and sediment dynamics. in Maltby,E.B., Barker,T. (ed.) The Wetlands Handbook. Chichester: Wiley-Blackwells, 120-168.

Bragg, O., 1991. Wedholme Flow, Cumbria: an ecohydrological study. Report to English Nature and Fisons Horticulture, Dundee University, Dundee.

Bravo, H.R., Jiang, F., Hunt, R.J., 2002. Using groundwater temperature data to constrain parameter estimation in a groundwater flow model of a wetland system. Water Resources Research, 38(8): 1153. 
Breuer, L., Eckhardt, K., Frede, H.-G., 2003. Plant parameter values for models in temperate climates. Ecological Modelling, 169(2): 237-293.

Bricker, S., Bloomfield, J., 2014. Controls on the basin-scale distribution of hydraulic conductivity of superficial deposits: a case study from the Thames Basin, UK. Quarterly Journal of Engineering Geology and Hydrogeology, 47(3): 223-236.

Bromley, J., Robinson, M., Barker, J., 2004. Scale-dependency of hydraulic conductivity: an example from Thorne Moor, a raised mire in South Yorkshire, UK. Hydrological processes, 18(5): 973-985.

Brown, J., Ingram, H., 1988. Changing storage beneath a stationary water table-an anomaly of certain humified peats. Quarterly Journal of Engineering Geology and Hydrogeology, 21(2): 177-182.

Camporese, M., Ferraris, S., Putti, M., Salandin, P., Teatini, P., 2006. Hydrological modeling in swelling/shrinking peat soils. Water resources research, 42(6).

Chambers, J. et al., 2014. Derivation of lowland riparian wetland deposit architecture using geophysical image analysis and interface detection. Water Resources Research, 50(7): 5886-5905.

Clymo, R., 2004. Hydraulic conductivity of peat at Ellergower Moss, Scotland. Hydrological Processes, 18(2): 261-274.

Crook, N. et al., 2008. Electrical resistivity imaging of the architecture of substream sediments. Water Resources Research, 44(4).

Crowe, A.S., Shikaze, S.G., Ptacek, C.J., 2004. Numerical modelling of groundwater flow and contaminant transport to Point Pelee marsh, Ontario, Canada. Hydrological Processes, 18(2): 293-314.

DHI, 2009. MIKE SHE user manual volume 1: user guide, DHI Water and Environment, Hørsholm, Denmark. 
Duan, Q., Sorooshian, S., Gupta, V., 1992. Effective and efficient global optimization for conceptual rainfall-runoff models. Water resources research, 28(4): 10151031.

EEC, 1992. Habitats Directive 92/43/EEC, Brussels.

Eglington, S.M. et al., 2010. Managing water levels on wet grasslands to improve foraging conditions for breeding northern lapwing Vanellus vanellus. Journal of Applied Ecology, 47(2): 451-458.

Elkington, T., Dayton, N., Jackson, D., Strachan, I., 1991. National Vegetation Classification: field guide to mires and heaths, Joint Nature Conservation Committee, Peterborough.

Everard, M., 2005. Water meadows. Forest Text, Wales.

Feyen, L., Vázquez, R., Christiaens, K., Sels, O., Feyen, J., 2000. Application of a distributed physically-based hydrological model to a medium size catchment. Hydrology and Earth System Sciences Discussions, 4(1): 47-63.

Frei, S., Lischeid, G., Fleckenstein, J., 2010. Effects of micro-topography on surface-subsurface exchange and runoff generation in a virtual riparian wetland-A modeling study. Advances in Water Resources, 33(11): 13881401.

Gowing, D. et al., 2002. The water regime requirements and the response to hydrological change of grassland plant communities. Final report to DEFRA, Cranfield University, Silsoe.

Graham, D.N., Butts, M.B., 2005. Flexible, integrated watershed modelling with MIKE SHE. Watershed models, 849336090: 245-272. 
Grapes, T., Bradley, C., Petts, G.E., 2006. Hydrodynamics of floodplain wetlands in a chalk catchment: The River Lambourn, UK. Journal of Hydrology, 320(3): 324-341.

Haria, A.H., Hodnett, M.G., Johnson, A.C., 2003. Mechanisms of groundwater recharge and pesticide penetration to a chalk aquifer in southern England. Journal of Hydrology, 275(1): 122-137.

Henriksen, H.J., Troldborg, L., Højberg, A.L., Refsgaard, J.C., 2008. Assessment of exploitable groundwater resources of Denmark by use of ensemble resource indicators and a numerical groundwater-surface water model. Journal of Hydrology, 348(1): 224-240.

House, A. et al., 2015. Discrete wetland groundwater discharges revealed with a three-dimensional temperature model and botanical indicators (Boxford, UK). Hydrogeology Journal: 1-13.

Huang, Y., Chen, X., Li, Y., Willems, P., Liu, T., 2010. Integrated modeling system for water resources management of Tarim River Basin. Environmental Engineering Science, 27(3): 255-269.

Hunt, R.J., Krabbenhoft, D.P., Anderson, M.P., 1996. Groundwater inflow measurements in wetland systems. Water Resources Research, 32(3): 495507.

Hunt, R.J., Walker, J.F., Krabbenhoft, D.P., 1999. Characterizing hydrology and the importance of ground-water discharge in natural and constructed wetlands. Wetlands, 19(2): 458-472.

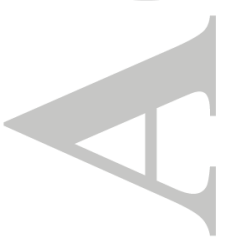


Jackson, C.R., Meister, R., Prudhomme, C., 2011. Modelling the effects of climate change and its uncertainty on UK Chalk groundwater resources from an ensemble of global climate model projections. Journal of Hydrology, 399(1): $12-28$.

Kettridge, N., Kellner, E., Price, J.S., Waddington, J.M., 2013. Peat deformation and biogenic gas bubbles control seasonal variations in peat hydraulic conductivity. Hydrological Processes, 27(22): 3208-3216.

Kneale, P.E., 1987. SENSITIVITY OF THE GROUNDWATER MOUND MODEL FOR PREDICTING MIRE TOPOGRAPHY. Nordic Hydrology, 18(4-5): 193-202.

Krause, S., Bronstert, A., 2005. An advanced approach for catchment delineation and water balance modelling within wetlands and floodplains. Advances in Geosciences, 5(5): 1-5.

Kristensen, K., Jensen, S., 1975. A model for investigating actual evapotranspiration from potential evapotranspiration. Nordic Hydrology, 6: 170-188.

Letts, M.G., Roulet, N.T., Comer, N.T., Skarupa, M.R., Verseghy, D.L., 2000. Parametrization of peatland hydraulic properties for the Canadian Land Surface Scheme. Atmosphere-Ocean, 38(1): 141-160.

Lischeid, G., Kolb, A., Alewell, C., Paul, S., 2007. Impact of redox and transport processes in a riparian wetland on stream water quality in the Fichtelgebirge region, southern Germany. Hydrological Processes, 21(1): 123-132.

Lowry, C.S., Walker, J.F., Hunt, R.J., Anderson, M.P., 2007. Identifying spatial variability of groundwater discharge in a wetland stream using a distributed temperature sensor. Water Resources Research, 43(10).

Madsen, $H_{\text {., }}$ 2000. Automatic calibration of a conceptual rainfall-runoff model using multiple objectives. Journal of hydrology, 235(3): 276-288. 
Madsen, H., 2003. Parameter estimation in distributed hydrological catchment modelling using automatic calibration with multiple objectives. Advances in water resources, 26(2): 205-216.

Maltby, E., Acreman, M.C., 2011. Ecosystem services of wetlands: pathfinder for a new paradigm. Hydrological Sciences Journal, 56(8): 1341-1359.

Marsh, T., Hannaford, J., 2008. UK Hydrometric register.

McClain, M.E. et al., 2003. Biogeochemical hot spots and hot moments at the interface of terrestrial and aquatic ecosystems. Ecosystems, 6(4): 301-312.

McMenamin, S.K., Hadly, E.A., Wright, C.K., 2008. Climatic change and wetland desiccation cause amphibian decline in Yellowstone National Park. Proceedings of the National Academy of Sciences, 105(44): 16988-16993.

Milsom, T.P., Hart, J.D., Parkin, W.K., Peel, S., 2002. Management of coastal grazing marshes for breeding waders: the importance of surface topography and wetness. Biological Conservation, 103(2): 199-207.

Milsom, T.P. et al., 2000. Habitat models of bird species' distribution: an aid to the management of coastal grazing marshes. Journal of Applied Ecology, 37(5): 706-727.

Mitsch, W.J., Gosselink, J.G., 2007. Wetlands. Hoboken. NJ: John Wiley \& Sons, Inc.

Monteith, J., 1965. Evaporation and the environment, The State and Movement of Water in Living Organisms, Proc. 15th Symposium Society for Experimental Biology , Swansea. Cambridge University Press, London, pp. 205-234.

Morris, J. et al., 2008. The economic dimensions of integrating flood management and agri-environment through washland creation: a case from Somerset, England. Journal of Environmental Management, 88(2): 372-381. 
Nash, J., Sutcliffe, J., 1970. River flow forecasting through conceptual models part I-A discussion of principles. Journal of hydrology, 10(3): 282-290.

Natural England, 2012. Condition of SSSI Units for Site Boxford Water Meadows.

Newbold, C., Mountford, J.O., 1997. Water level requirements of wetland plants and animals. English Nature.

Old, G. et al., 2014. Instream and riparian implications of weed cutting in a chalk river. Ecological Engineering, 71: 290-300.

Plum, N., 2005. Terrestrial invertebrates in flooded grassland: A literature review. Wetlands, 25(3): 721-737.

Price, J.S., 2003. Role and character of seasonal peat soil deformation on the hydrology of undisturbed and cutover peatlands. Water Resources Research, $39(9)$.

Refsgaard, J., Storm, B., 1995. MIKE SHE. In: Singh, V. (Ed.), Computer Models of Watershed Hydrology. Water Resources Publications, Englewood, USA, pp. 809-846.

Refsgaard, J.C. et al., 1998. An Integrated Model for the Danubian Lowland Methodology and Applications. Water Resources Management, 12(6): 433465.

Singh, C., Thompson, J.R., French, J.R., Kingston, D.G., Mackay, A.W., 2010. Modelling the impact of prescribed global warming on runoff from headwater catchments of the Irrawaddy River and their implications for the water level regime of Loktak Lake, northeast India. Hydrology and Earth System Sciences, 14(9): 1745-1765. 
Singh, C., Thompson, J.R., Kingston, D.G., French, J.R., 2011. Modelling water-level options for ecosystem services and assessment of climate change: Loktak Lake, northeast India. Hydrological Sciences Journal, 56(8): 1518-1542.

Smart, J., Amar, A., O'Brien, M., Grice, P., Smith, K., 2008. Changing land management of lowland wet grasslands of the UK: impacts on snipe abundance and habitat quality. Animal Conservation, 11(4): 339-351.

Sophocleous, M., 2002. Interactions between groundwater and surface water: the state of the science. Hydrogeology Journal, 10(1): 52-67.

Sorensen, J.P., Butcher, A.S., 2011. Water Level Monitoring Pressure Transducers-A Need for Industry-Wide Standards. Ground Water Monitoring \& Remediation, 31(4): 56-62.

Staes, J., Rubarenzya, M.H., Meire, P., Willems, P., 2009. Modelling hydrological effects of wetland restoration: a differentiated view. Water Science and Technology, 59(3): 433-441.

Stisen, S., Jensen, K.H., Sandholt, I., Grimes, D.I., 2008. A remote sensing driven distributed hydrological model of the Senegal River basin. Journal of Hydrology, 354(1): 131-148.

Tattersfield, P., Mclnnes, R., 2003. Hydrological requirements of Vertigo moulinsiana on three candidate Special Areas of Conservation in England (Gastropoda, Pulmonata: Vertiginidae). Heldia, 5(7): 135-147.

Thompson, J.R., 2012. Modelling the impacts of climate change on upland catchments in southwest Scotland using MIKE SHE and the UKCP09 probabilistic projections. Hydrology Research, 43(4): 507-530. 
Thompson, J.R., Green, A.J., Kingston, D.G., 2014. Potential evapotranspirationrelated uncertainty in climate change impacts on river flow: An assessment for the Mekong River basin. Journal of Hydrology, 510: 259-279.

Thompson, J.R., Green, A.J., Kingston, D.G., Gosling, S.N., 2013. Assessment of uncertainty in river flow projections for the Mekong River using multiple GCMs and hydrological models. Journal of hydrology, 486: 1-30.

Thompson, J.R., Gavin, H., Refsgaard, A., Sorenson, H.R., Gowing, D.J., 2009. Modelling the hydrological impacts of climate change on UK lowland wet grassland. Wetlands Ecology and Management, 17(5): 503-523.

Thompson, J.R., Sorenson, H.R., Gavin, H., Refsgaard, A., 2004. Application of the coupled MIKE SHE/MIKE 11 modelling system to a lowland wet grassland in southeast England. Journal of Hydrology, 293(1-4): 151-179.

Van Genuchten, M.T., 1980. A closed-form equation for predicting the hydraulic conductivity of unsaturated soils. Soil science society of America journal, 44(5): 892-898.

Vázquez, R., Feyen, L., Feyen, J., Refsgaard, J., 2002. Effect of grid size on effective parameters and model performance of the MIKE-SHE code. Hydrological Processes, 16(2): 355-372.

Wheeler, B., Brooks, A., 2004. Ecohydrological guidelines for lowland wetland plant communities. Environment Agency.

Wheeler, B., Shaw, S., Tanner, K., 2009. A wetland framework for impact assessment at statutory sites in England and Wales. Environment Agency R\&D Technical Report.

Winter, T.C., 1999. Relation of streams, lakes, and wetlands to groundwater flow systems. Hydrogeology Journal, 7(1): 28-45. 
Younger, P., 1989. Devensian periglacial influences on the development of spatially variable permeability in the Chalk of southeast England. Quarterly Journal of Engineering Geology and Hydrogeology, 22(4): 343-354.

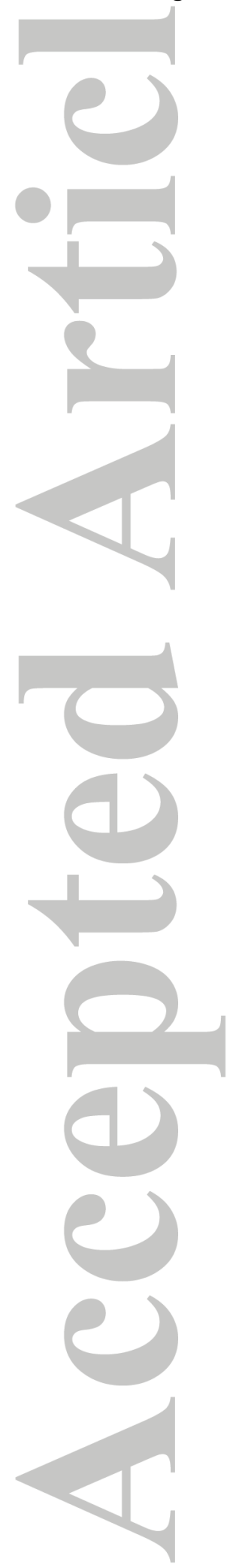


Table 1. Calibrated parameter values

\begin{tabular}{ll}
\hline Parameter & Calibrated value \\
\hline Unsaturated zone effective saturation & 0.93 \\
Unsaturated zone infiltration rate $\left(\mathrm{ms}^{-1}\right)$ & $2.30 \times 10^{-5}$ \\
Peat horizontal hydraulic conductivity $\left(\mathrm{ms}^{-1}\right)$ & $1.98 \times 10^{-5}$ \\
Peat vertical hydraulic conductivity $\left(\mathrm{ms}^{-1}\right)$ & $9.53 \times 10^{-6}$ \\
Gravel horizontal hydraulic conductivity $\left(\mathrm{ms}^{-1}\right)$ & $2.93 \times 10^{-4}$ \\
Gravel vertical hydraulic conductivity $\left(\mathrm{ms}^{-1}\right)$ & $6.98 \times 10^{-4}$ \\
Manning's n coefficient for overland flow $\left(\mathrm{sm}^{-1 / 3}\right)$ & 0.03 \\
\hline
\end{tabular}

This article is protected by copyright. All rights reserved. 
Table 2. Model performance statistics for head elevations in peat (P) and gravel $(G)$ piezometers and River Lambourn (L) and Westbrook (W) stage over the calibration $(1 / 2 / 2013$ - 1/12/2013) and validation (1/12/2013 - 1/10/2014) periods. Model performance indicators are adapted from Henriksen et al. (2008)

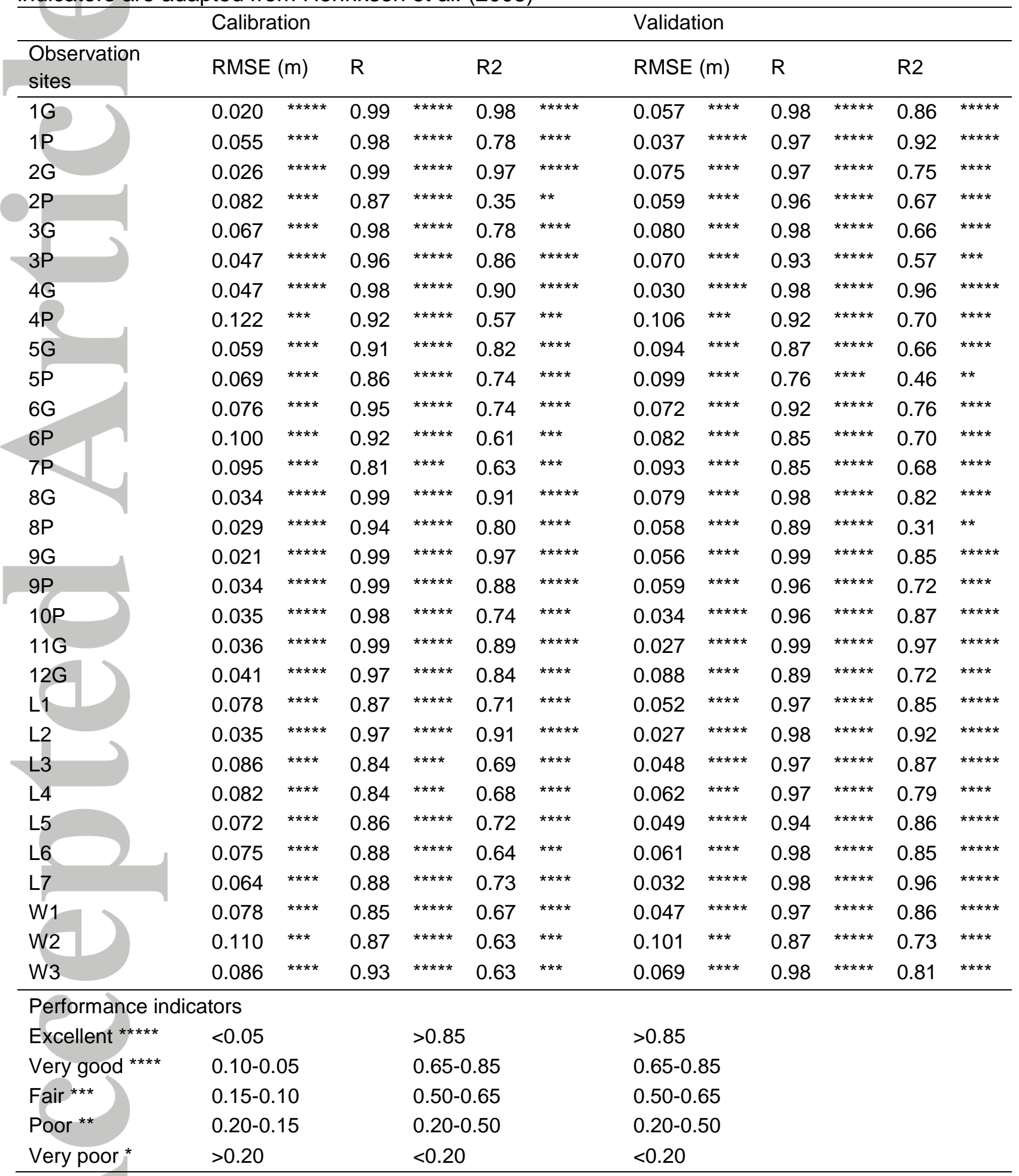

This article is protected by copyright. All rights reserved. 
Table 3. Simulated monthly and total water balance for the CEH River Lambourn Observatory. All values in $\mathrm{mm}$. P, precipitation; ET, evapotranspiration; I, interception storage; SW, net surface water outflow; SWS, change in surface water storage; GW, net groundwater inflow; GWS, change in groundwater storage; B, baseflow

\begin{tabular}{lrrrrrrrrr}
\hline Month & \multicolumn{1}{c}{$\mathbf{P}$} & \multicolumn{1}{c}{ ET } & \multicolumn{1}{c}{ S } & \multicolumn{1}{c}{ SWS } & GW & GWS & B & Error \\
\hline Feb-13 & 6.40 & 9.03 & 0 & 136.61 & -10.22 & 145.93 & 4.17 & -0.01 & -0.64 \\
Mar-13 & 26.55 & 12.25 & $1.70 \times 10^{-5}$ & 156.72 & -7.84 & 152.50 & -2.71 & -0.06 & 0.52 \\
Apr-13 & 9.60 & 31.35 & $-9.42 \times 10^{-6}$ & 53.00 & -25.48 & 106.06 & -3.46 & 0.10 & -2.44 \\
May-13 & 14.65 & 27.13 & $-5.52 \times 10^{-6}$ & 172.27 & 31.85 & 146.47 & 5.33 & -0.11 & 1.20 \\
Jun-13 & 5.75 & 22.77 & 0 & 83.14 & -6.27 & 106.91 & -1.89 & 0.05 & 1.36 \\
Jul-13 & 11.25 & 21.86 & $-3.20 \times 10^{-5}$ & 118.00 & 13.76 & 104.60 & 9.49 & 0.07 & 0.69 \\
Aug-13 & 5.90 & 17.67 & $2.90 \times 10^{-5}$ & 127.78 & 1.70 & 133.56 & 4.50 & 0.24 & -0.46 \\
Sep-13 & 17.20 & 8.88 & $3.73 \times 10^{-5}$ & 123.41 & -0.27 & 115.69 & -0.42 & 0.23 & -0.13 \\
Oct-13 & 31.10 & 15.44 & $-2.20 \times 10^{-1}$ & 134.65 & -0.14 & 117.98 & 0.75 & 0.17 & 0.46 \\
Nov-13 & 15.30 & 7.06 & $2.20 \times 10^{-1}$ & 124.49 & 0.79 & 112.08 & 2.40 & 0.10 & 0.66 \\
Dec-13 & 37.45 & 11.48 & $-4.59 \times 10^{-2}$ & 158.78 & -1.03 & 138.42 & -4.07 & -0.20 & -0.28 \\
Jan-14 & 50.70 & 11.77 & $-1.08 \times 10^{-1}$ & 210.23 & -7.47 & 189.50 & -9.56 & -0.27 & -0.80 \\
Feb-14 & 31.95 & 20.72 & $1.54 \times 10^{-1}$ & 151.53 & -16.54 & 161.20 & -4.77 & -0.07 & 0.46 \\
Mar-14 & 5.15 & 18.00 & $-6.34 \times 10^{-5}$ & 163.00 & 14.15 & 158.30 & 3.44 & -0.06 & -0.03 \\
Apr-14 & 24.10 & 15.88 & $-5.32 \times 10^{-2}$ & 115.10 & -7.03 & 115.30 & -2.15 & 0.00 & 0.66 \\
May-14 & 20.90 & 21.68 & $5.32 \times 10^{-2}$ & 130.60 & 13.49 & 111.40 & 7.50 & 0.00 & -1.07 \\
Jun-14 & 15.50 & 15.87 & $-4.97 \times 10^{-2}$ & 122.40 & 0.63 & 121.50 & -0.14 & 0.15 & 0.84 \\
Jul-14 & 9.10 & 20.16 & $4.97 \times 10^{-2}$ & 105.50 & 1.05 & 113.50 & 2.15 & 0.09 & -0.38 \\
Aug-14 & 21.35 & 20.97 & $-1.47 \times 10^{-4}$ & 100.90 & 1.66 & 94.80 & 3.72 & 0.39 & 0.03 \\
Sep-14 & 7.95 & 4.97 & $-5.45 \times 10^{-5}$ & 98.20 & 0.87 & 89.90 & 3.21 & 0.34 & 0.88 \\
\hline Total & 367.86 & 335.42 & $1.67 \times 10^{-4}$ & 2589.30 & -2.33 & 2538.80 & 17.60 & 1.17 & 1.61 \\
\hline
\end{tabular}

This article is protected by copyright. All rights reserved. 

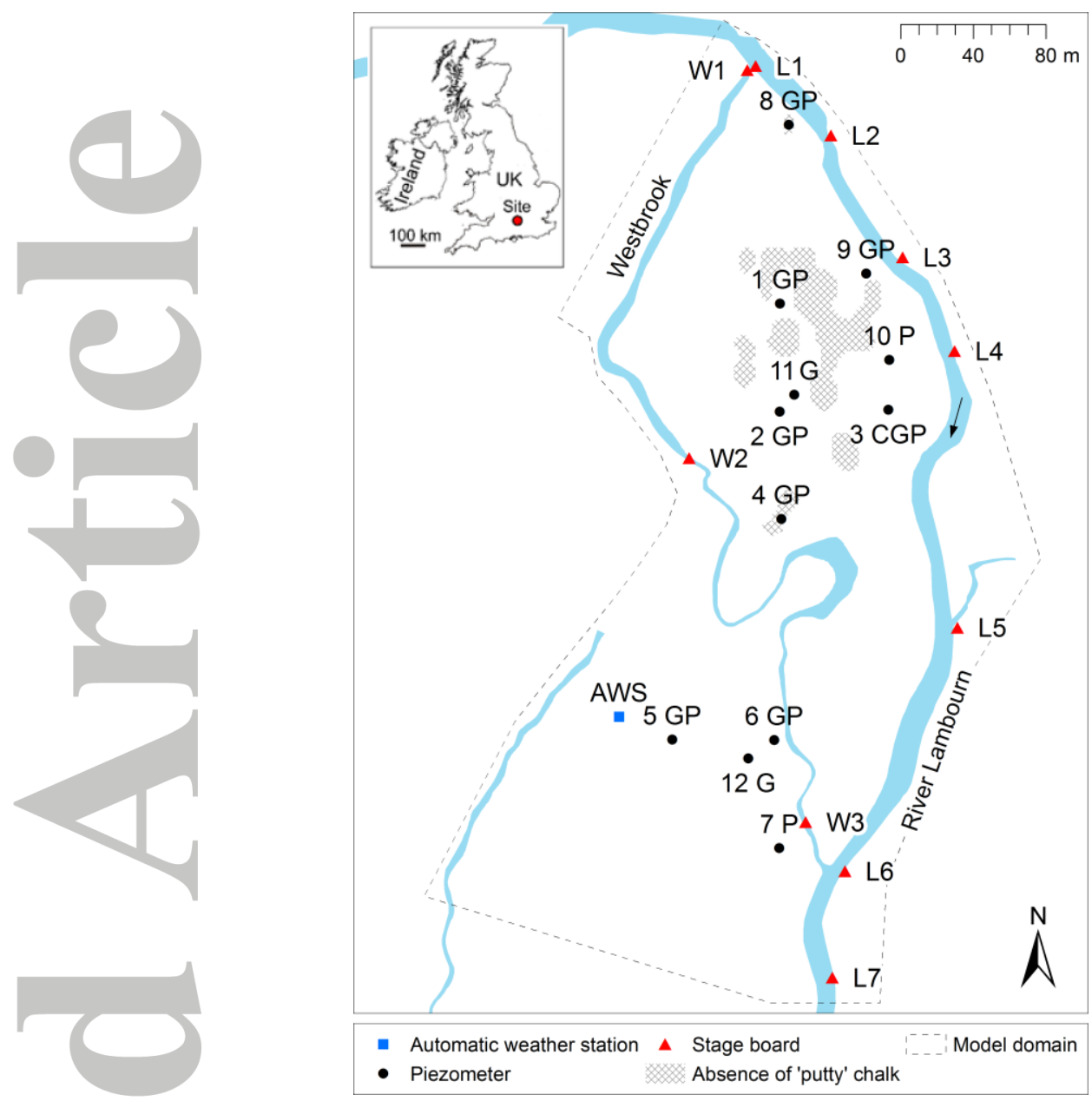

Figure 1. The CEH River Lambourn Observatory showing the instrumentation network with chalk $(\mathrm{C})$, gravel $(\mathrm{G})$ and peat $(\mathrm{P})$ piezometer locations, model domain, and horizontal extent of absences in highly weathered 'putty' chalk 


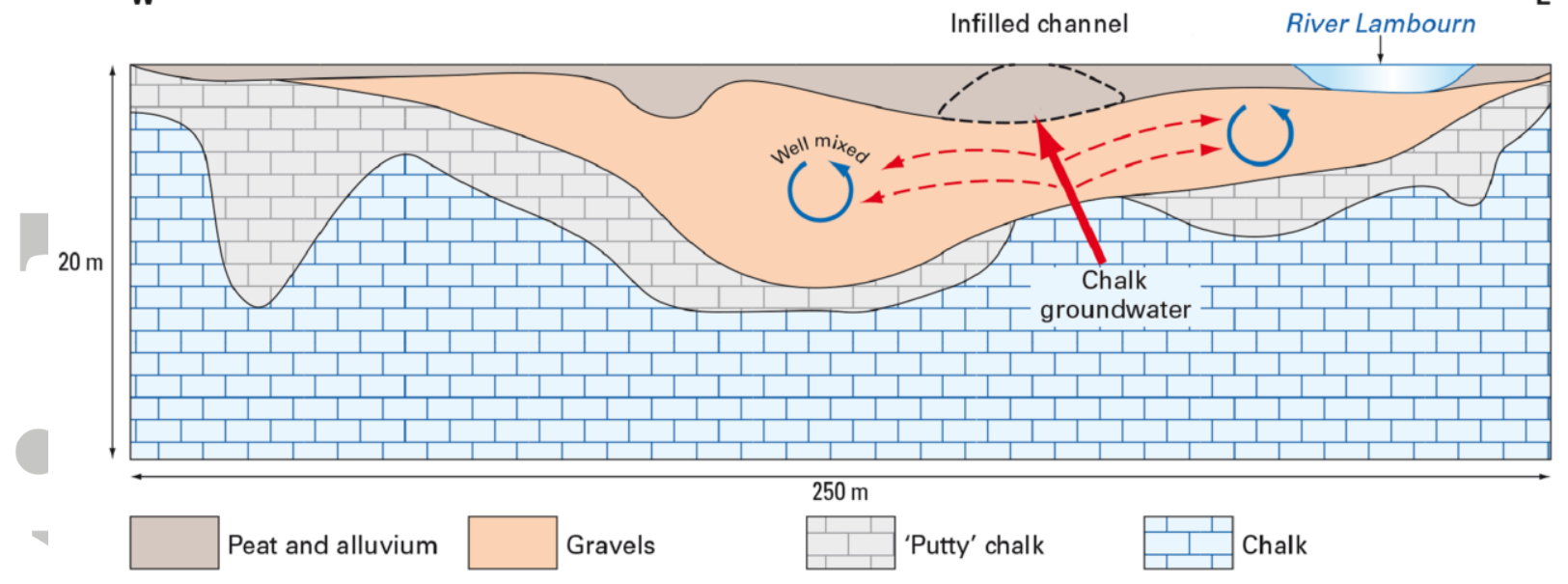

Figure 2. Conceptual vertical section through the River Lambourn Observatory, after House et al. (2015)
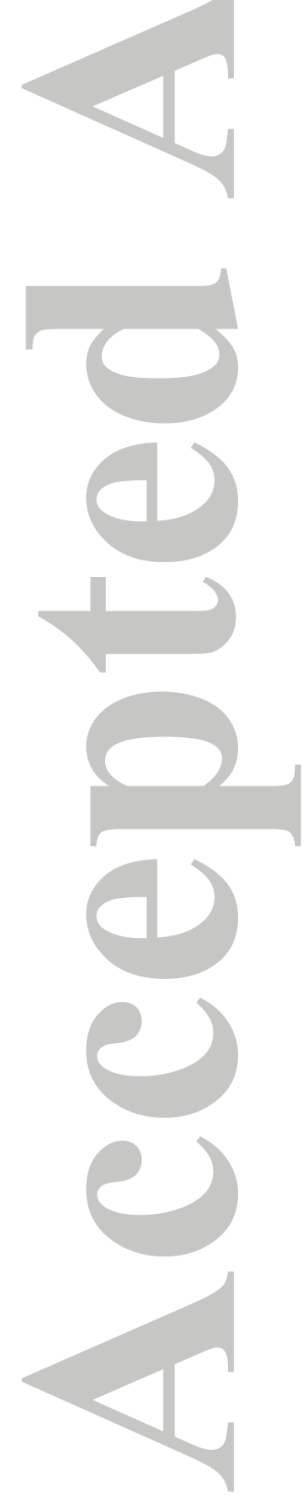

This article is protected by copyright. All rights reserved. 


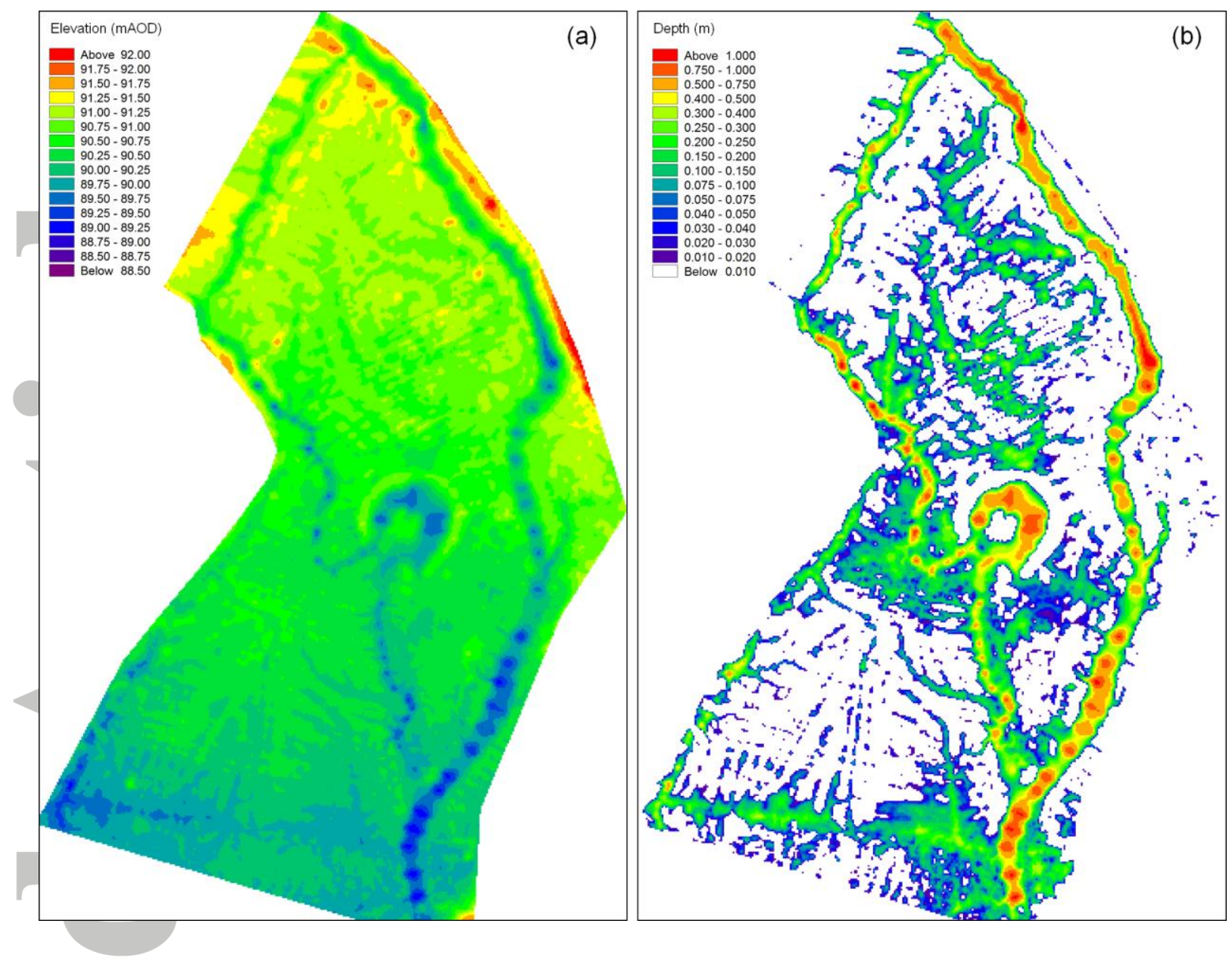

Figure 3. (a) $1 \mathrm{~m} \times 1 \mathrm{~m}$ MIKE SHE topographic grid of the River Lambourn Observatory, and (b) extent and depth of surface water at peak flow (15/2/2014)

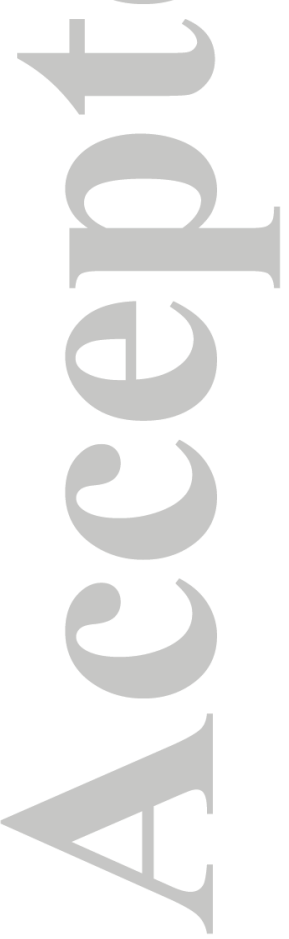

This article is protected by copyright. All rights reserved. 

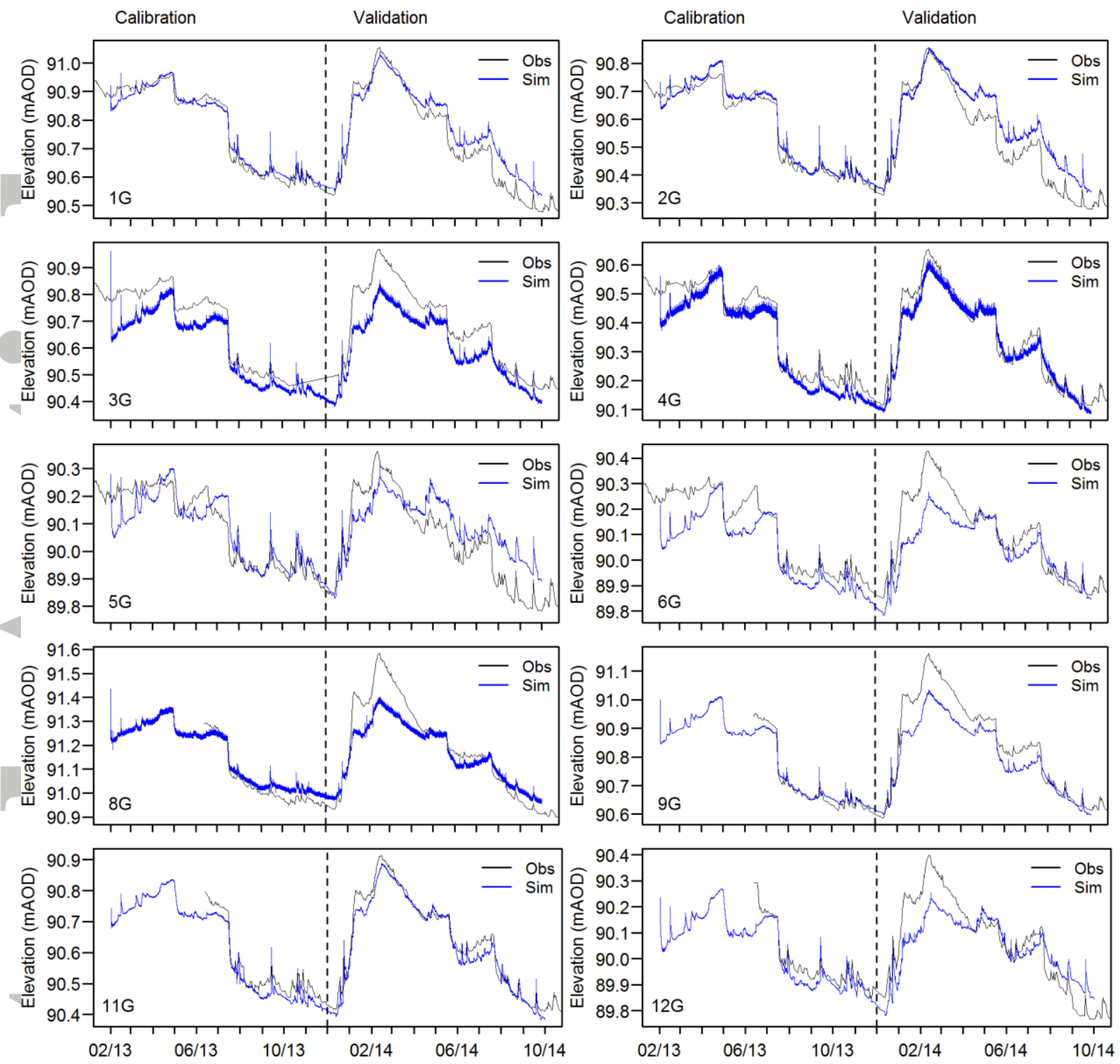

Figure 4. Observed and simulated groundwater head elevations (mAOD) in gravel $(G)$ piezometers at locations 1-6, 8, 9, 11 and 12 

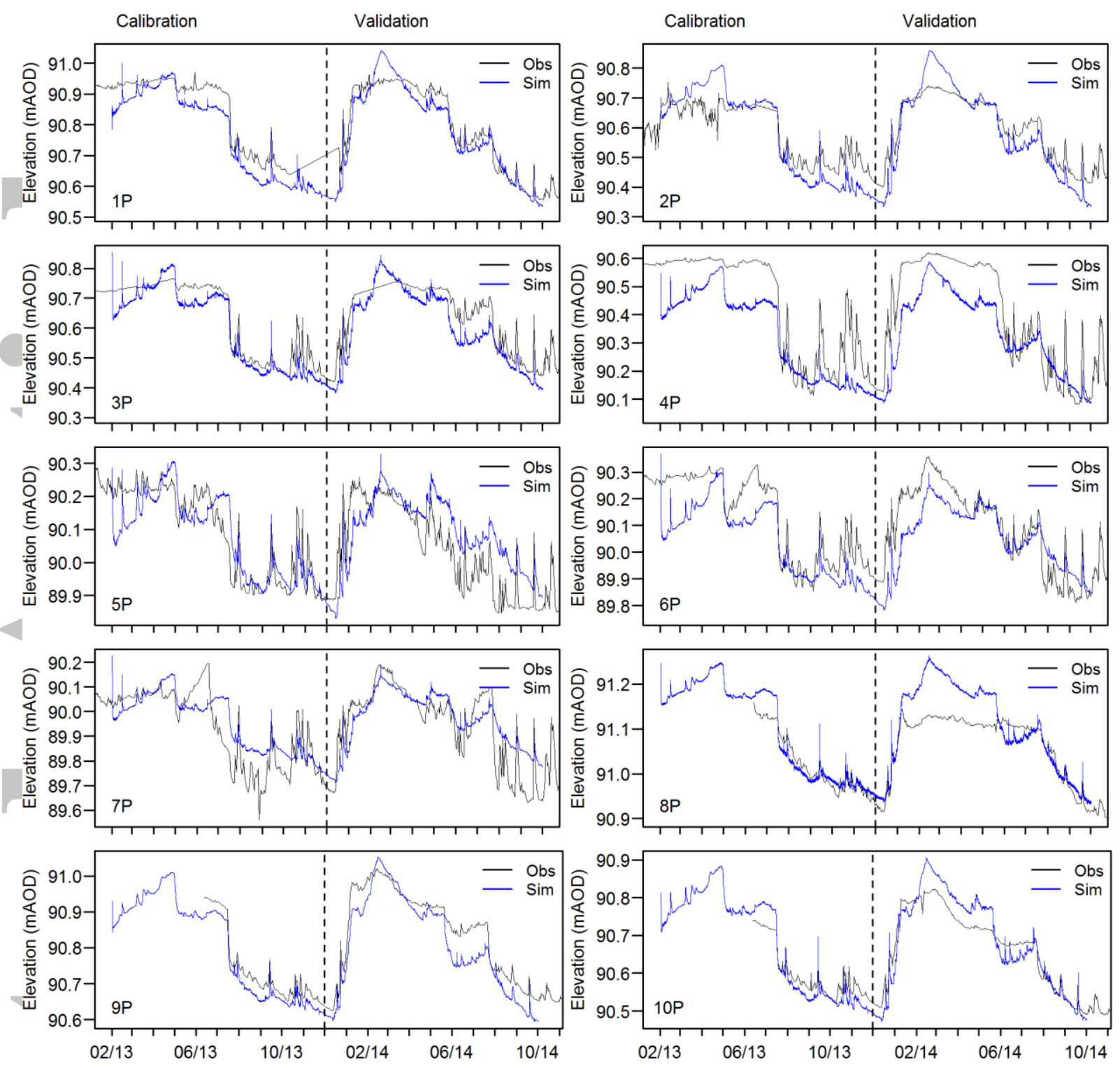

Figure 5. Observed and simulated groundwater head elevations (mAOD) in peat $(P)$ piezometers at locations $1-10$ 

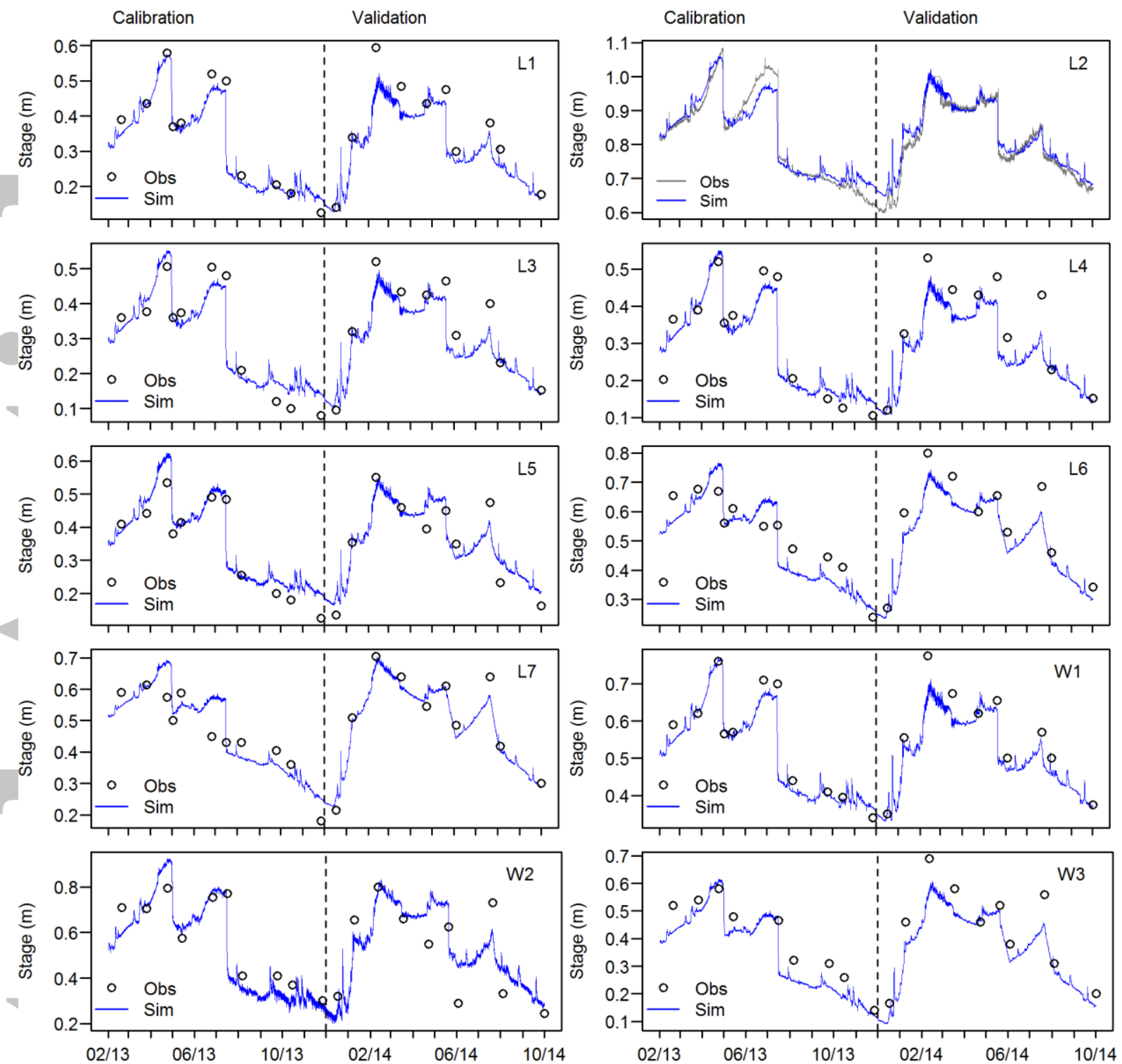

Figure 6. Observed and simulated channel stage for the River Lambourn (L) and Westbrook (W) 


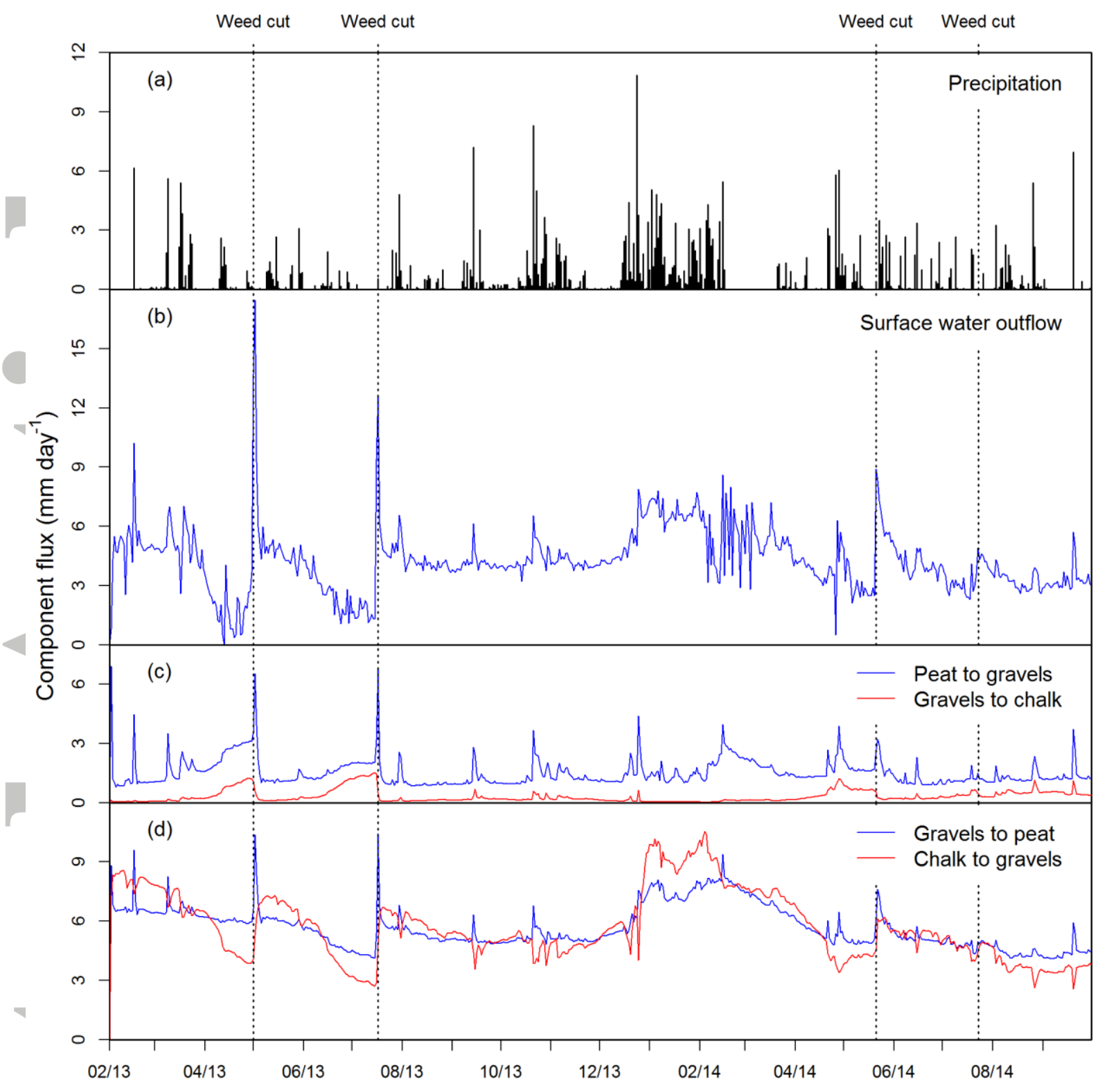

Figure 7. Detailed components of the water balance: (a) precipitation, (b) surface water outflow, (c) downward groundwater flow between geological layers, and (d) upward groundwater flow between geological layers 

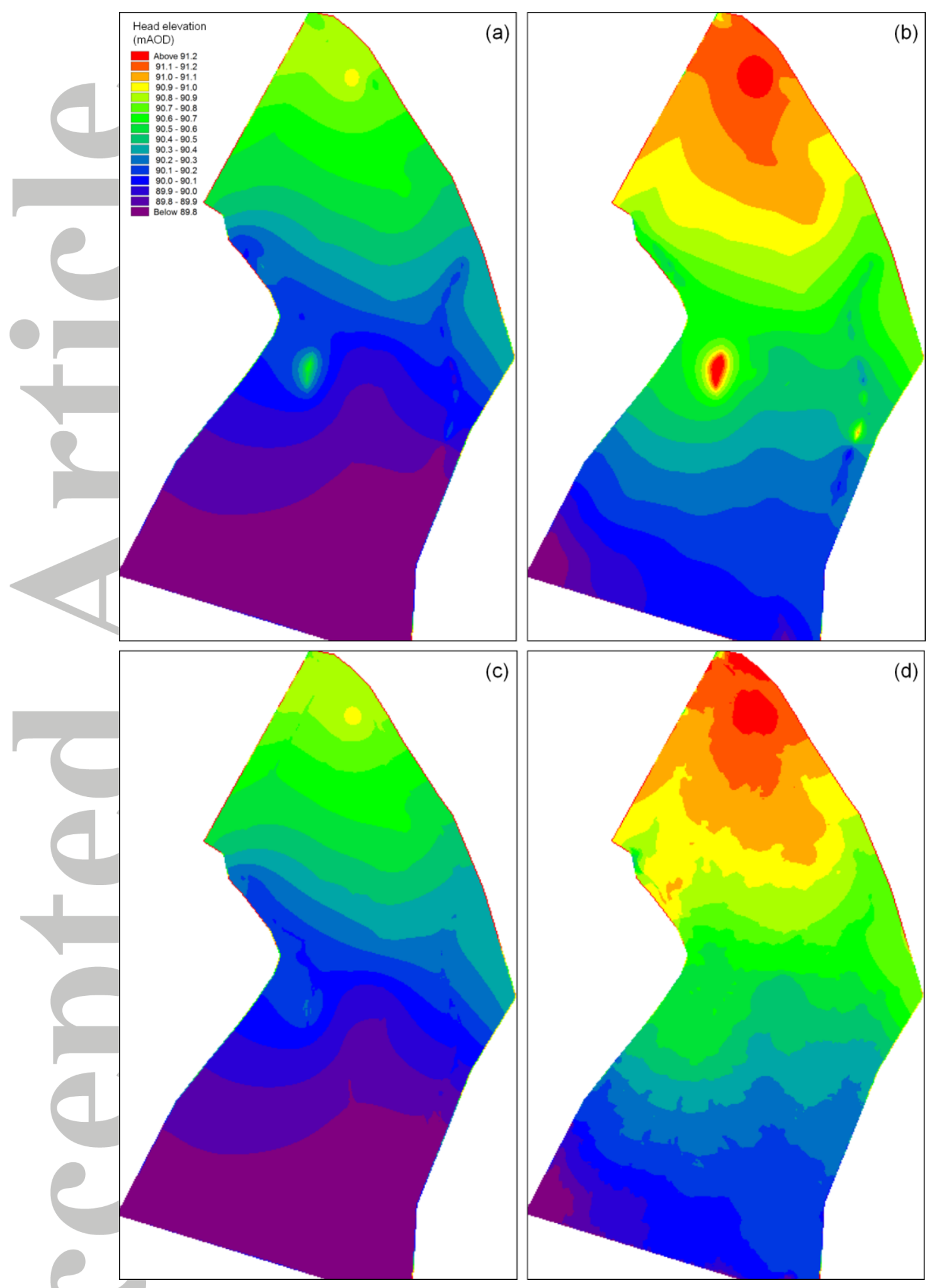

Figure 8. Head elevations in (a) gravels at lowest head elevation (12/12/2013), (b) gravels at highest head elevation (15/2/2014), (c) peat at lowest head elevation (12/12/2013), and (d) peat at highest head elevation (12/2/2014) 